\title{
Westerncentric in the Design of Costumes in Javanese Dance Opera in the XVIII Century
}

\author{
R. M. Pramutomo (Corresponding author) \\ Indonesia Institute of the Arts Surakarta \\ Indonesia \\ E-mail: rmpram60@gmail.com \\ Riva Amelia \\ University of Limerick \\ Ireland \\ E-mail: rivaamelia2207@gmail.com
}

Received: February 21, 2021

Accepted: March 23, 2021 Published: March 25, 2021

doi:10.5296/ijch.v8i1.18436

URL: https://doi.org/10.5296/ijch.v8i1.18436

\begin{abstract}
The 18th century Javanese performance art has given an artistic expression of the aristocrats known as the Langendriya genre. Langendriya's performing arts are the creativity of the Yogyakarta royal aristocrats who are recognized as the prototype of Javanese opera art. The creator of the Langendriya opera is Prince of Mangkubumi, the younger brother of Sultan Hamengku Buwana VII, the seventh king of the Yogyakarta kingdom. In the process of creation, Prince of Mangkubumi was assisted by his two sons, KRT. Kertanegara and KRT. Wiraguna. Through KRT Wiraguna figure Langendriya opera fashion design gets a European touch by combining Western designs and Javanese designs. This article wants to reveal the uniqueness of the Western design model applied to the Javanese designs created by KRT Wiraguna. As a new creation, the combination of Western and Javanese works by KRT Wiraguna became phenomenal in the 18th century. This article is written using historical methods combined with ethnochoreological methods as the scientific basis for opera drama. Therefore, ethnocoreological analysis will be useful in the application of design in the form of the body of the dance opera that is presented.
\end{abstract}


Keywords: costume design, dance opera, Langendriya, ethnochoreology, embodiment

\section{Introduction}

One of the important genres of Yogyakarta-style dance in the study of pseudo-absolutism is Langendriya. The art of Langendriya drama is declared as the first Javanese dance opera created in Indonesia. The creator of this opera drama is K.G.P.A.A. Mangkubumi, a son of Sultan Hamengkubuwana VI and served as lurah pangeran as well as Adjutant to the Governor-General in Yogyakarta at that time. This dance opera form was not originally created for performing arts purposes. Even K.G.P.A.A. Mangkubumi, apart from being known for creating Langendriya, also created the female golek tunggal dance genre which became the prototype for the Yogyakarta-style golek dance. ${ }^{1}$ This golek dance was created at the same time as the formation of the Javanese opera drama Langendriya, because the main function of the golek dance at that time was as a closing part of Langendriya performances at the Kadipaten. (Note 1)

In B. Sularto's writing, it is explained that one part of the formation of Javanese opera drama art was made in the house of a high noble called nDalem Kadipatèn (Sularto; 1982: 46--47). In principle, the Lengendriya opera drama is more accurately said to be a form of creativity from a high noble family that meets the standards of innovation and experimentation, both physically and technically-artistic. For this reason, it can be argued, that the original idea for the composition of the Langendriya opera drama was not only from K.G.P.A.A. Mangkubumi himself. Moving on from the macapatan tradition at nDalem Kadipatèn every month of Ramadan or fasting, as a substitute for dance practice activities. This is a custom that has been traditionally enforced in the homes of the high nobility. One of Mangkubumi's sons, namely R.M. Sutandar made a suggestion to choose one of the writings of Serat Damarwulan to be read together at that time. This step gave rise to an idea to do this by moving the hands and the head as an addition to artistic expression in reading the tembang text from Serat Damarwulan. The suggestion to move the hand and part of the head was captured by his father to develop it for certain characters as the life force of the Damarwulan story.

R.M. Sutandar who had the title K.R.T. Kertanegara begged to his father to witness the changes that manifested into the text of the song dialogue and hand and neck movements. Mangkubumi fulfilled his son's request by watching a tembang play a lakon from the Damarwulan story entitled Jumenengan Nata Dewi K Datingawungu (Sularto; 47--49). After watching the tembang performance with a story taken from the Serat Damarwulan above, Mangkubumi immediately delivered his corrections and criticisms. Mangkubumi's observations are concentrated on the awareness of aspects of the performing arts, in the sense of a genre presentation. This is revealed that there some weaknesses in the form of motion and fashion as well as the details of the scenes that require a certain dramatic accentuation. On that basis, he then ordered one of his other sons, K.R.T. Wiraguna to arrange fashion designs and a number of properties and accessories (Sularto; 48). A gesture was suggested by Mangkubumi that the new genre of costume designs should not be the same as those in the Kraton Yogyakarta.

To fulfill his father's request, Wiraguna immediately came up with the idea of a combination 
of European-style designs with Javanese-style designs. Especially in the form of clothes and headdresses, such as feathers and jamang, or headbands. Several designs of male role dancers use a lot of European hat designs. Meanwhile, the female dancer's dress, the combination of European and Javanese colors typical of Mataraman, still looks proportional. Such is the creative work of K.G.P.A.A. Mangkubumi combined with K.R.T.'s artistic ideas Kertanegara and K.R.T.'s innovative design contributions. Wiraguna makes the completeness of Langendriya's presentation form a Javanese opera dance drama genre approaching perfection. Sularto in his comments stated that Langendriya as a form of Javanese opera drama is one of the most valuable products in the history of traditional Indonesian theater (Sularto; 1982: 45--47).

This article is the result of research on dance opera attire which first appeared in Java in the early nineteenth century. This article is written using the historical method combined with the ethnocoreological method. The historical method is due to the fact that many document sources and archives are used as sources to see aesthetic phenomena contained in photographic records and documents. Meanwhile, the use of the ethnocoreological method is because the material object under study is a type of dance opera performance art. Apart from that, the application of ethnocoreological analysis is preferred because it relates to Langendriya's artistic product as a prototype of Javanese dance opera. There is a common interest when historical and ethnochoreological methods are combined. As in Jill-Buckland's statement that history is needed because the background of an art phenomenon can always be known through various forms of notes, in the form of documents or archives that have been made by the perpetrator (Jill Buckland ed; 2005: 3-5). According to Jill-Buckland, ethnocoreology is a scientific basis that places dance material in the dance ethnography. The ethnocoreological view of the dance ethnography is part of the description that gives the data the authenticity of aesthetic phenomena. This is in the ethnocoreological analysis pointed out by R.M. Pramutomo when he saw a dance study (and dance opera) as a study of non-Western ethnic dance (and dance opera) culture (R.M. Pramutomo ed.; 2007: 1-3).

\section{Authentic Phenomena}

The description of the emergence of the Javanese opera drama era was expressed in the presence of another opera drama, namely Langendriya. It is just that the reference to creation is more likely to be referred from oral sources. This book strongly believes in the beginning of the creation of Javanese opera drama which was born around the years 1860-1863 Suharto; 1999: 16--18). Meanwhile, the reference to the number of years is obtained from the prototype of the Javanese opera drama that was born earlier, namely Langendriya, that was mentioned by the Dutch writer Th. B. Van Lelyveld. In the data Lelyveld uses the number 1876 as a reference for the creation of the Yogyakarta-style Langendriya. This year might be the closest to the number of years written in the text of Serat Kandha Langendriya Babon Mangkubumen which dates back to 1870. The text of the Langendriya Babon Mangkubumen manuscript is still preserved at the residence of R.M. Dinusatomo., Kadipaten Wetan, Yogyakarta. In addition, the supporting data which states Langen Mandra Wanara's appearance was later than Langendriya is described from the results of an interview with a descendant of K.P.H. Yudanegara III. It was explained that one of the descendants of K.P.H. 
Yudanegara is K.R.T. Yudakusuma. On that basis, this book is an important source to examine an era in the formation of Javanese opera dance drama, which started from the birth of Langendriya to the birth of Langen Mandra Wanara in the Yogyakarta style. The both opera drama genres mentioned above simultaneously appeared in a period of the reign of Sultan Hamengkubuwana VII (1877-1921). This era is believed to be an era of continuation of the laying of the foundation for the development of Yogyakarta-style dance. The study of Javanese dance performance in the Yogyakarta style cannot possibly ignore the era of Sultan Hamengkubuwana VII's reign as a unique era.

One of these uniqueness data can be proven from the process of the emergence of two Javanese opera dance genres that were born outside the walls of the Kraton. As it is known, that Langendriya was created at Kadipatèn Anom, which became the official residence of K.G.P.A.A. Mangkubumi (Sultan Hamengkubuwana VII's younger brother). Meanwhile Langen Mandra Wanara was created at the Patih Yogyakarta official residence, which was originally named K.P.H. Yudanegara III, and after becoming Patih was given the name Danureja VII (Ngayugyakarta Pagelaran Manuscript t.t. Number D34 / W77; Mahadeva Collection). In turn, another important benefit can be obtained from this book in examining the status of the location for the creation of the Yogyakarta style opera drama genre, and its relation to the political status of the Sultan.

Another important book has also been written by Sri Rochana Widyastutieningrum, entitled Langendriyan Mangkunegaran: Formation and Development of the Presentation Forms, published in 2005. This book was originally a research result of a genre of Javanese opera drama dance born in Mangkunegaran Palace, Surakarta. The importance of this book's reference can be observed from the phenomenon of its birth which was contemporaneous with the era of opera drama in Yogyakarta. In fact, it is very possible that there can be mutual influence between its emergence and formation. The assumptions expressed in this literature are also supported by valid historical data.

At the beginning of this book, Rochana refers to the figure R.M.T. Tandakusuma who is an important figure behind the opera drama Langendriyan Mangkunegaran. This character originally wrote the lakon text based on the Damarwulan story with the name Langendriyan Mandraswara (Rochana; 2005: 6-7). One of the interesting views of this book is derived from Koentjaraningrat's statement about Langendriyan Mangkunegaran's relationship with Langendriya in Yogyakarta. It was stated that the presence of Langendriyan Mangkunegaran had a connection with Langendriya, which first developed in Yogyakarta at the end of the 19th century. Even the genre developed in Mangkunegaran is predicted to have originated from Yogyakarta (Rochana: 7).

Apart from that, through the existing photographic data in Yogyakarta it is known that the oldest photographic data in the Javanese opera drama Langendriya, Yogyakarta style is from 1895. ${ }^{2}$ A more recent visual source comes from photographic data in 1907 showing when K.R.T. Wiraguna played Adipati Sindhura in the Langendriya performance for the wedding of Crown Prince III Hamengku Buwana VII (G.R.M. Putra) with his younger sister, R.Aj. Siti Katinah, at the Yogyakarta Palace. At that time, a red, white, and blue symbol of the Dutch 
royal flag had been arranged in the background of the show. (Note 2)

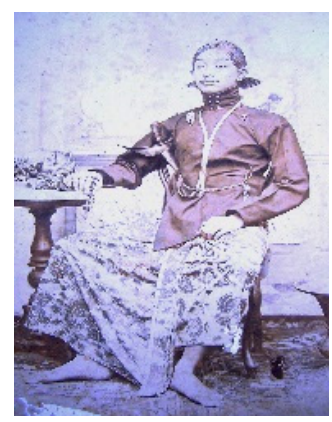

Figure 1. Wiraguna, creator of Langendriya fashion designs in Yogyakarta style 1904 (Photo: Collection of Center of Arts Archives and Documents Studies Yogyakrta)

\section{Langendriya: Its Visual Characterization}

Referring to the comparison of the character types above, it is possible to convey a number of visual variants of motion which are only applied incompletely. This understanding is based on the traditional view, that the role of the characters in Langendriya does not have a complete variety in the jejer scene as in the Wayang Wong art in the Yogyakarta Palace (R.M. Pramutomo; 2015: 23--26). Therefore, the most observable form of motion is the shade pattern which can still be observed for its main variety. As mentioned earlier, there are very few visual variants of the tayungan motion pattern that refers to the main variety.

Meanwhile, a small number of gecul characters that exist, they do not have any major variants. This is only explained as in "lampah mégol semar jengkeng" for tayungan. Observing the minimal variance of a number of variants of tayungan patterns based on the main types of motion, it can be stated that on tayungan pattern is based on the main variations in the style of the Yogyakarta-style Langendriya genre only consist of tayungan impur alus, kalang kinantang gagah, bapang gagah, and lampah pocong putri patterns. Those four patterns of visual variance of motion can be further divided into six types of characters as follows.

1. The female character type is refined and humble,

2.The female character type is delicate and dynamic,

3. The male character type is refined and humble,

4.The male character type is smooth and dynamic,

5. The male character types are dashing and dynamic,

6. The male character types are dashing, aggressive, and rude.

\section{Costumes Design}

Regarding the term which is then referred to as dance opera or opera drama in the book will 


\section{Macrothink}

be explained as follows. Opera in a Western perspective is one of the musical drama genres which presents a play with dialogue using songs and accompanied by a complete orchestra (Sommerset-Ward; 1998: 79--81). This term is clearly not one hundred percent correct if its use in the Langendriya context refers to the term opera from a Western perspective. However, at least it can be referred to from the use of dialogue elements that use singing, this can be paralleled in the sense of opera drama. If in the development of Western opera, the ballet opera genre appears, then this may be closer to the term Javanese opera drama in the Langendriya genre. In this sense, the Langendriya opera drama is a play in which the conversations are sung and the movements of the performers are danced. According to Sularto, Langendriya is the first genre form of Javanese dance opera in the treasury of traditional Javanese theater (Sularto: 1987; 44--45). This assumption clearly does not have a reliable reference from the perspective used. As the perspective of opera art from the Western view clearly cannot be matched with Langendriya, however, if it refers to opera ballet art, then it is still quite close to the element of presenting the dialogue being sung. One thing that shows the similarity in the form of aesthetic reality is that the two typologies of opera, both from the Western and Eastern perspectives, are both an elite performance art.

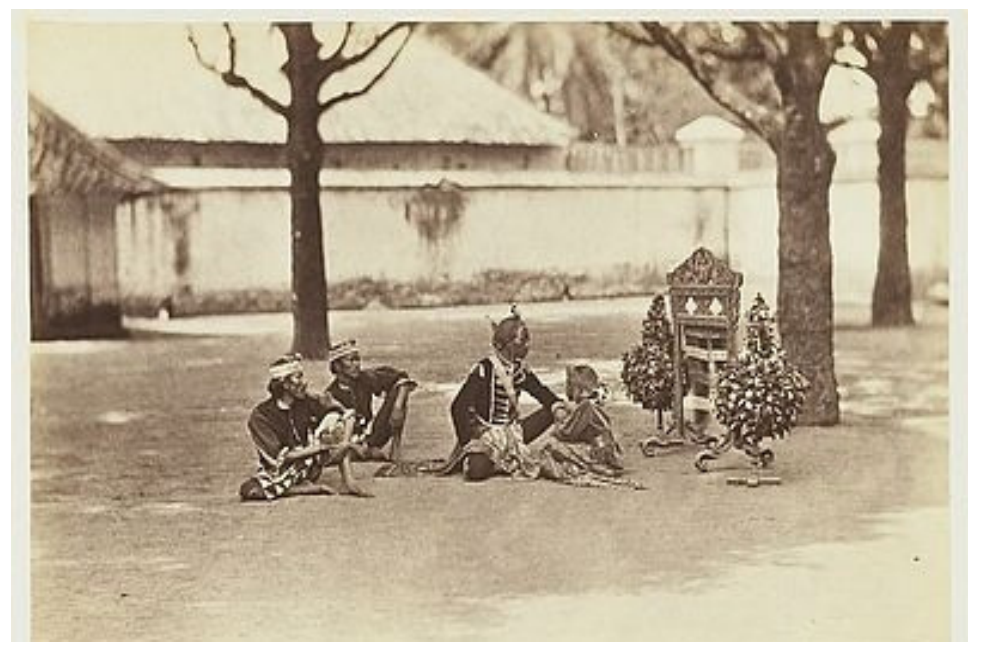

Figure 2. Damarwulan the main role of Langendriya, Yogyakarta style 1885

(Photo: KITLV Collection, Leiden) 


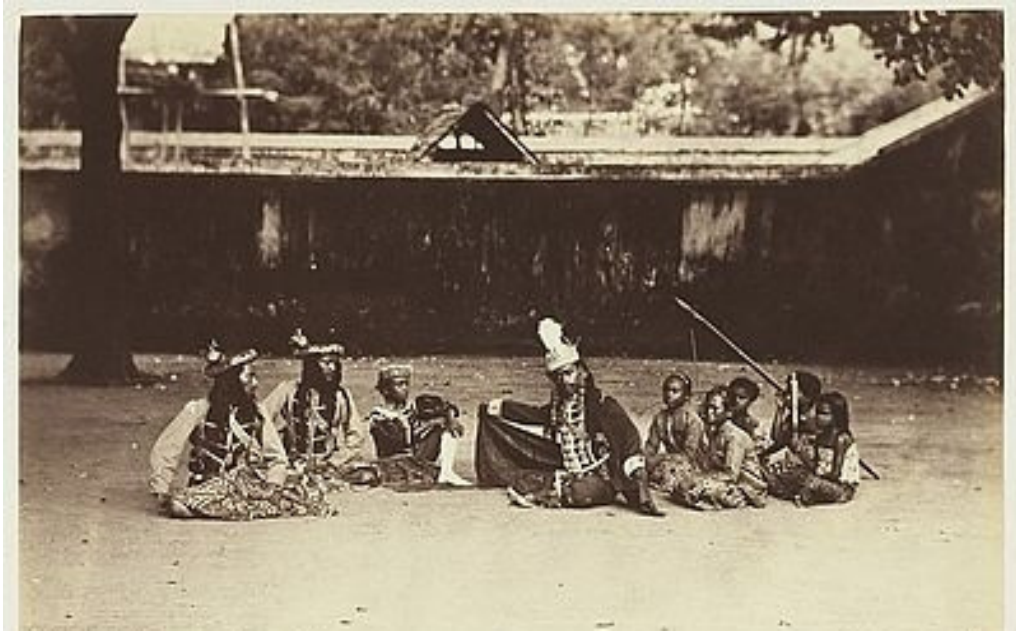

Figure 3. The scene Menak Jingga nglana an antagonist role of Langendriya Yogyakarta style, 1895 (Photo: KITLV Collection, Leiden)

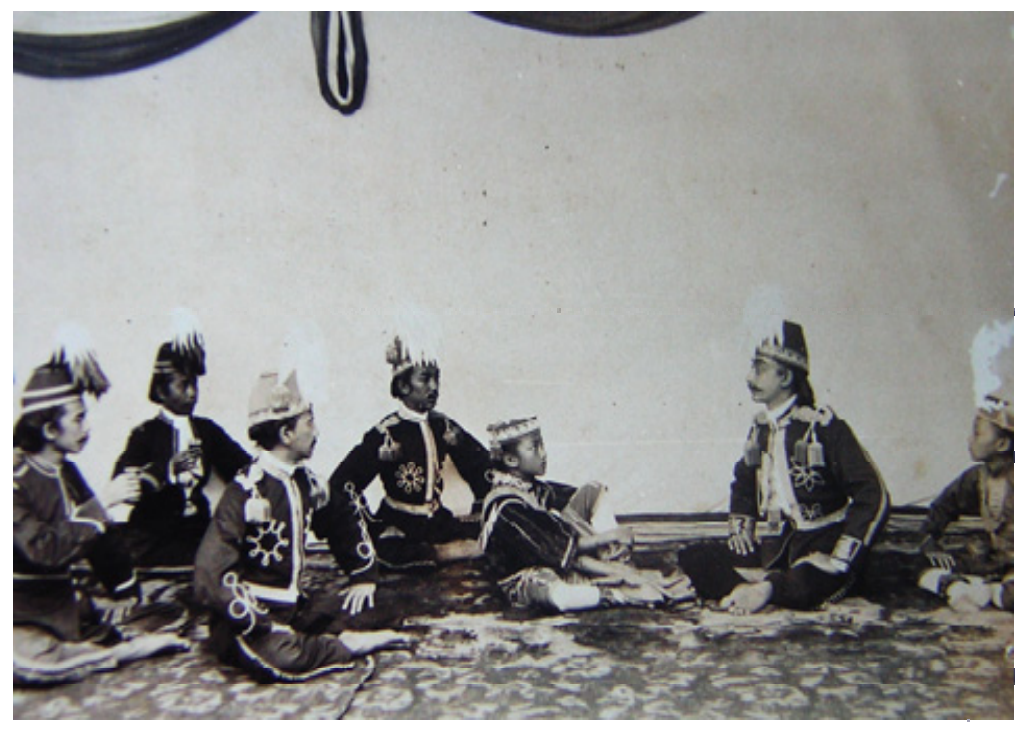

Figure 4. Sitting on the right is Wiroguno who acts as Adipati Sindhura at the Langendriya performance in 1907 (Photo Collections of K.R.T. Wiroguno Center for the Study of Archives and Art Documents, Yogyakarta, 1907). 


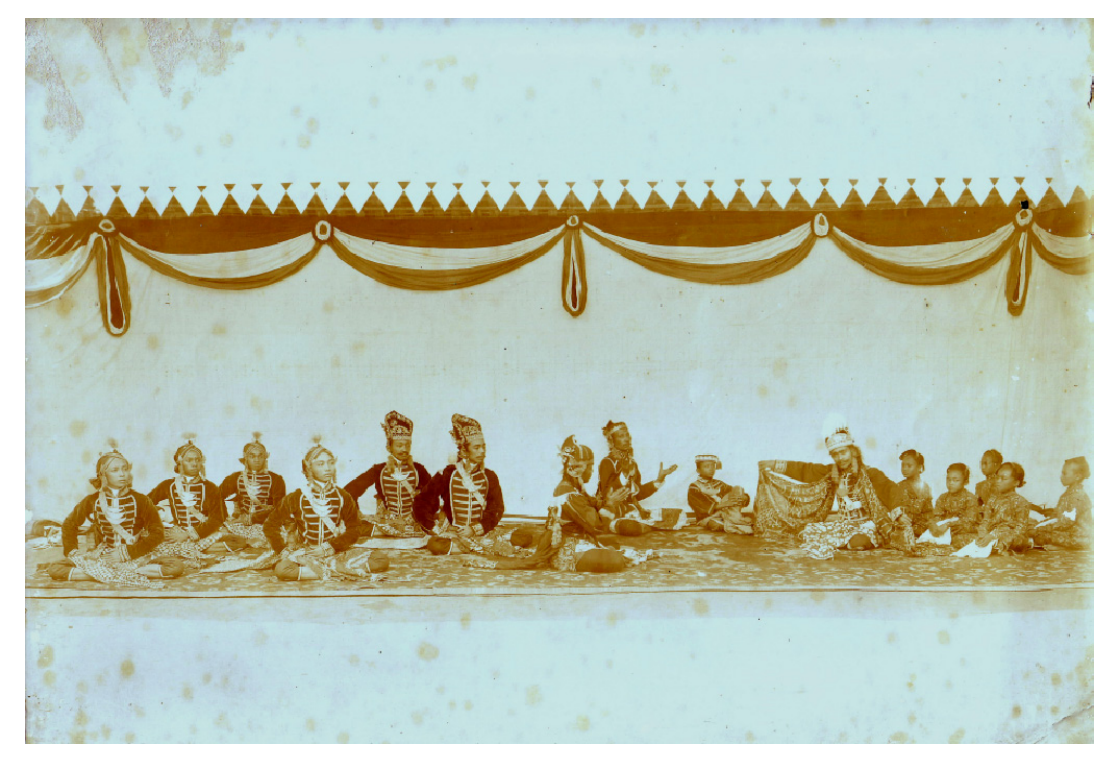

Figure 5. The scene of Blambangan Kingdom of Langendriya, Yogyakarta style in 1907 (Photo Collection Center for the Study of Archives and Art Documents K.R.T. Wiroguno, Yogyakarta)

An artistic product conception and a strata of "prestige" have been described by Arnold Hauser:

Artistic productivity and receptivity, it is true, closely linked with the existence of privilliged strata, but artistic ability and social privilleges are not the same as one another (Hauser; 1979; 549).

Hauser includes the 'prestige' factor as one of the patterns of artistic productivity stemming from elite status. Hauser's conception above is also closely related to the division of categories of high culture. This category was proposed by Hauser as a hallmark of the court performing arts genre in the past (See Hauser; 1979: 549--550). This status can also have the meaning of cultural texts. One of the main reasons for the placement of this meaning, is that the form of art created from the Javanese aristocratic environment becomes the contextuality of Javanese values towards power. In the early period of the formation of the Langendriya genre at nDalem Mangkubumen, it turned out that in addition to the aristocratic elite who were present there were also several artists from the general public who were very interested in this opera drama genre.

\section{Conclusion}

This article has discussed an 18th century Javanese art phenomenon. This phenomenon of art was created from an expression of the aristocrats known as the Langendriya genre. Langendriya's performing arts are the creativity of the Yogyakarta royal aristocrats who are recognized as the prototype of Javanese opera art. In the process of creation, Prince Mangkubumi was assisted by his two sons, namely KRT. Kertanegara and KRT. Wiraguna. 
Through KRT figures. Wiroguna's Langendriya opera fashion design gets a European touch by combining Western designs and Javanese designs.

Western cultural touch patterns were explored as an 18th century westerncentric trend. In the end, this article also reveals the uniqueness of the Western design model that is applied to KRT's Javanese designs. Wiraguna. As a new creation of a combination of Western and Javanese works by KRT. Wiraguna became a phenomenon in the 18th century. The westerncentric meaning does not imply Javanese characteristics in certain designs. On the visual aspect, the westerncentric pattern is nuanced and adaptive. The thing that really stands out is the design of the clothes and accessories of the Langendriya drama. Therefore, the westerncentric pattern in accessories and clothing designs became the artistic value of the Langendriya opera drama, which became phenomenal in the 18 th century.

\section{References}

Arnold Hauser. (1979). The Sociology of Art. Terj. Kenneth J. Northcott, Chicago and London: The University of Chicago Press.

Ben Suharto et al. (1999). Langen Mandra Wanara. Yogyakarta: Dinas Kebudayaan DIY.

Jill-Buckland, T. (2006). Dance from Past to Present. Wisconsin: The University of Wisconsin Press.

Ngayugyakarta Pagelaran No. D 34/W 77, (Koleksi Widya Budaya Kraton Yogyakarta).

Pramutomo, R. M. (2015). Jejak Sosio-Historis Penciptaan Dramatari Jawa. Surakarta: ISI Press Solo.

Richard Sommerset-Ward. (1998). The Story of Opera. New York and London: Henry Abrahms.

Sarasilah Paguyuban Kadangkadeyan Mangkubumen. (2004).

Sri Rochana, W. (2005). Langendriyan Mangkunegaran: Pembentukan dan Perkembangan Bentuk Penyajiannya. Surakarta: ISI Press.

Sularto, B. (1982). K.G.P.A. Mangkubumi: Hasil Karya dan Pengabdiannya. Yogyakarta: Departemen Pendidikan dan Kebudayaan.

\section{Notes}

Note 1. Not less than various genres of female golek tunggal dance were created during his life, including: Golek Gambyong, Golek Gegar Mayang, Golek Pocung Kethoprak, Golek Surengrana, Golek Layung Seta, Golek Ngreni, Golek Jangkung Kuning, Golek Gambir Sawit, Golek Calunthang, Golek Kutut Manggung, and so on.

Note 2. Information based on the date of the shooting by Kassian Chepas from 1885 to 1895 at the Yogyakarta Palace. It is likely that the Yogyakarta-style Langendriya was very 


\section{Macrothink}

International Journal of Culture and History

ISSN 2332-5518

2021, Vol. 8, No. 1

memorable in the heart of Sultan Hamengkubuwana VII at that time. many of these are stored in the photography collection of KITLV Leiden, Netherlands.

\section{Copyrights}

Copyright for this article is retained by the author(s), with first publication rights granted to the journal.

This is an open-access article distributed under the terms and conditions of the Creative Commons Attribution license (http://creativecommons.org/licenses/by/4.0/) 